\title{
Soil losses in the State of Rondônia, Brazil
}

\section{Guilherme Henrique Expedito Lense ${ }^{1}$ (D) Taya Cristo Parreiras ${ }^{1}$ (D) Velibor Spalevic ${ }^{2}$ (DD Junior Cesar Avanzi ${ }^{3}$ iD Ronaldo Luiz Mincato ${ }^{4 *}$ (D)}

\author{
${ }^{1}$ Programa de Pós-graduação em Ciências Ambientais, Universidade Federal de Alfenas (UNIFAL-MG), Alfenas, Minas Gerais, Brasil. \\ ${ }^{2}$ Faculty of Philosophy, Geography, University of Montenegro (UCG), Niksic, Montenegro. \\ ${ }^{3}$ Departamento de Ciência do Solo, Universidade Federal de Lavras (UFLA), Lavras, Minas Gerais, Brasil. \\ ${ }^{4}$ Instituto de Ciências da Natureza, Universidade Federal de Alfenas (UNIFAL-MG), 37130-000, Alfenas, Minas Gerais, Brasil. E-mail: \\ ronaldo.mincato@unifal-mg.edu.br. Corresponding author.
}

\begin{abstract}
In the state of Rondonia, deforestation, and inadequate soil use and management have intensified the water erosion process, causing degradation of agricultural land. Modeling is a tool that can assist in the adoption of targeted and effective measures for soil and water conservation in the region. In this context, the objective of the research was to model soil losses due to water erosion in the state of Rondonia using the Revised Universal Soil Loss Equation (RUSLE). The parameters related to rain erosivity, relief, erodibility, and soil cover, as well as the conservation practices of the state of Rondonia, were considered. The modeling steps were performed with the aid of the Geographic Information System. Results were validated with data of total sediments transported with water discharge. The estimated total soil loss was about 605 million tons per year, corresponding to an average loss of $22.50 \mathrm{Mg} \mathrm{ha}^{-1}$ year ${ }^{-1}$. In $19 \%$ of the state, the erosion rate was higher than the soil loss tolerance(T), and these areas should be prioritized for adopting measures to mitigate the erosion process. The RUSLE underestimated the generation of sediments at $0.56 \mathrm{Mg} \mathrm{ha}^{-1}$ year ${ }^{-1}$, which corresponds to an error of $18.60 \%$. Results obtained can assist in the development of different soil use and management scenarios and provide options for policymakers to encourage soil conservation in the state of Rondônia.
\end{abstract}

Key words: water erosion, soil conservation, RUSLE, amazon region.

Perdas de solo no Estado de Rondônia, Brasil

RESUMO: No Estado de Rondônia, o desmatamento, o uso e o manejo inadequado dos solos têm intensificado o processo de erosão hídrica, gerando a degradação de terras agrícolas. Nesse cenário, a modelagem é uma ferramenta que pode auxiliar na adoção de medidas direcionadas e eficazes de conservação do solo e da água na região. Assim, o objetivo do trabalho foi modelar as perdas de solo por erosão hídrica no Estado de Rondônia utilizando a Equação Universal de Perda de Solo Revisada (RUSLE). Foram considerados os parâmetros referentes a erosividade da chuva, relevo, erodibilidade e cobertura do solo e as práticas conservacionistas do Estado de Rondônia. As etapas da modelagem foram realizadas com auxílio de Sistema de Informações Geográficas. Os resultados foram validados com dados de coleta de sedimentos totais transportados com a descarga d'água. A perda de solo total estimada foi cerca de 605 milhões de toneladas ao ano, correspondente a uma perda média de 22,50 $\mathrm{Mg} \mathrm{ha}^{-1}$ ano ${ }^{-1}$. Em 19\% do Estado a taxa erosiva foi superior aos limites de tolerância de perda de solo (TPS), sendo que essas áreas devem ser priorizadas para adoção de medidas de mitigação do processo erosivo. A RUSLE subestimou a geração de sedimentos em 0,56 $\mathrm{Mg} \mathrm{ha}^{-1}$ ano-1, o que corresponde a um erro de $18,60 \%$. Os resultados obtidos podem contribuir para elaborar distintos cenários de manejo e uso do solo e fornecer alternativas aos formuladores de políticas agrícolas e ambientais, com o intuito de incentivo a conservação do solo no Estado de Rondônia.

Palavras-chave: erosão hídrica, conservação do solo, RUSLE, região amazônica.

\section{INTRODUCTION}

The state of Rondônia was the scene of several changes in land use and occupation, marked by developmental public policies and territorial occupation based on the removal of native vegetation (PIONTEKOWSKI et al., 2014). Extensive areas of Amazonian forest have been converted to crops and pastures with inadequate agricultural practices. Currently, the state of Rondôniais still one of the most affected by deforestation in the Brazilian Amazon (INPE, 2020). According to SCHLINDEWEIN et al. (2012), deforestation, combined with inadequate soil management and the high rate of precipitation in the northern region of Brazil, intensified the water erosion process, generating a loss of nutrients and organic matter, and the degradation of Rondônia agricultural lands.

The modeling of water erosion is a tool that can assist in the adoption of appropriate and 
efficient measures for soil and water conservation in Rondônia. Erosion models increase our understanding of environmental processes and facilitate land use and occupation planning, as well as decisionmaking in watershed management (PANAGOS \& KATSOYIANNIS, 2019). Also, this type of approach positively influences the proposition and adoption of agricultural and environmental policies to control water erosion (ALEWELL et al., 2019, MEDEIROS et al., 2016).

The modeling is based on mathematical equations that express the relationships between natural factors (rain, soil cover, soil properties, and topography) and the erosion process. Among the modeling techniques, the Revised Universal Soil Loss Equation - RUSLE (RENARD et al., 1997) deserves to be highlighted because it is a model widely used in Brazil and worldwide. The RUSLE is a flexible model, applicable in different regions, with different edaphoclimatic conditions, and the determination of its parameters is easy. Moreover, extensive scientific literature compare and assess the efficiency of RUSLE results (ALEWELL et al., 2019).

The RUSLE application can be easily integrated into the Geographic Information System, allowing estimation of soil losses on a large scale and the spatialization of the results (GANASRI \& RAMESH, 2016; BARROS et al., 2018). Therefore, given the above, the objective of the research was to model soil losses due to water erosion in the state of Rondônia, using RUSLE.

\section{MATERIALS AND METHODS}

\section{Study area description}

The State of Rondônia covers an area of $237,574 \mathrm{~km}^{2}$, located in the northern region of Brazil, between the coordinates $66^{\circ} 36^{\prime} 49^{\prime \prime}$ to $60^{\circ} 43^{\prime} 17^{\prime \prime} \mathrm{W}$, and $13^{\circ} 41^{\prime} 57^{\prime \prime}$ to $7^{\circ} 58^{\prime} 33^{\prime \prime} \mathrm{S}$, Datum SIRGAS 2000 (Figure 1). The climate of the region, according to the Köppen classification, is the Aw type (rainy tropical), with average annual temperatures around $25.5^{\circ} \mathrm{C}$ and an annual rainfall regime over 2,000 $\mathrm{mm}$ (ALVARES et al., 2013; PIONTEKOWSKI et al., 2014).

The state is mainly occupied by the Amazon Forest (62.55\%), pastures (32.92\%), other natural formations $(2.45 \%)$, agriculture $(1.02 \%)$, water bodies $(0.90 \%)$, urbanization $(0.15 \%)$ and other non-vegetated areas $(0.01 \%)$. The land use and occupation map (Figure 1) was adapted from the Map Biomas Project (2018).

The soil classes of the region are mostly Latosols (38.5\%), Argisols (30.7\%), and Neosols $(14.4 \%)$, and other soil classes are illustrated in Figure 2A, which was prepared using the digital soil map of Brazil on scale 1:5,000,000 (IBGE; EMBRAPA, 2001). Although, the region presents an average altitude of $206 \mathrm{~m}$, the maximum exceeds $1,126 \mathrm{~m}$, at the Pico do Tracuá, the mountain range of Pacaás Novos (Figure 2B). The digital elevation model (DEM), with a spatial resolution of 30 meters, was extracted from the digital platform named Brazil in Relief (MIRANDA, 2005),

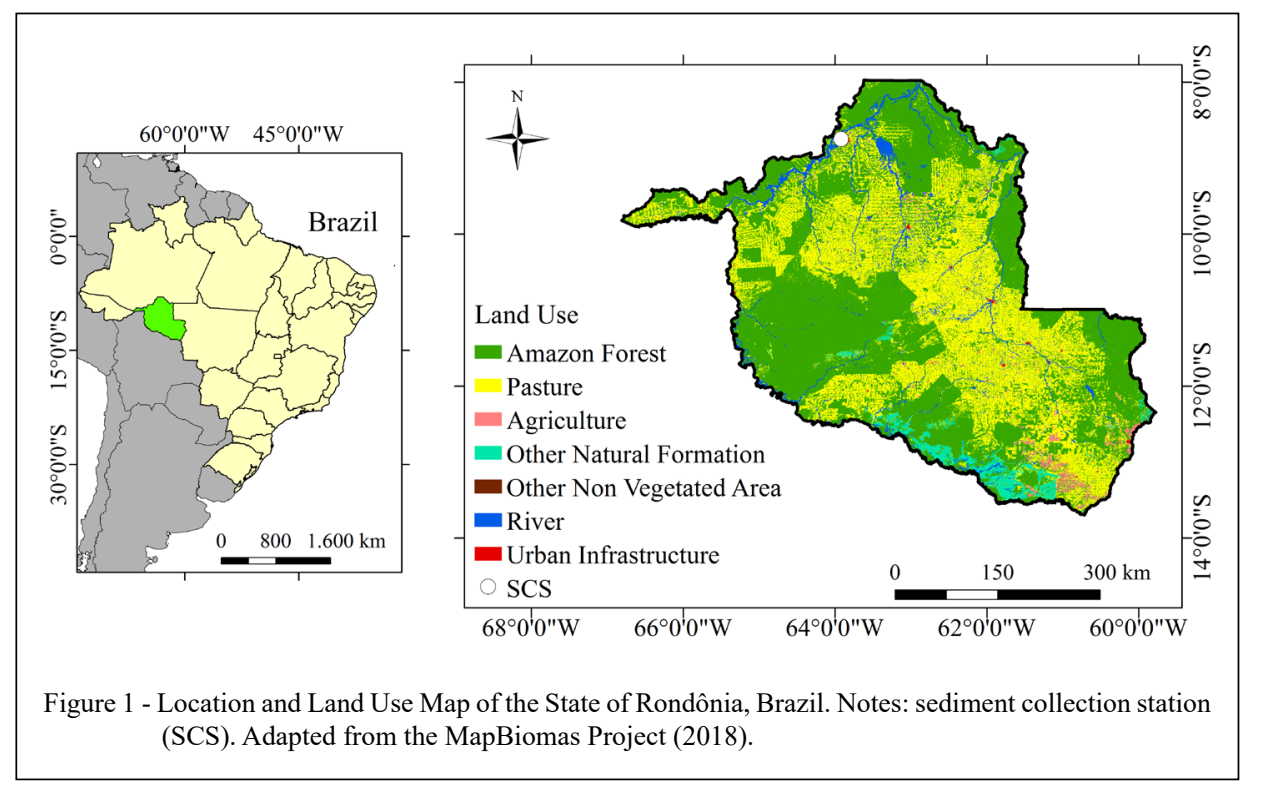

Ciência Rural, v.51, n.5, 2021. 

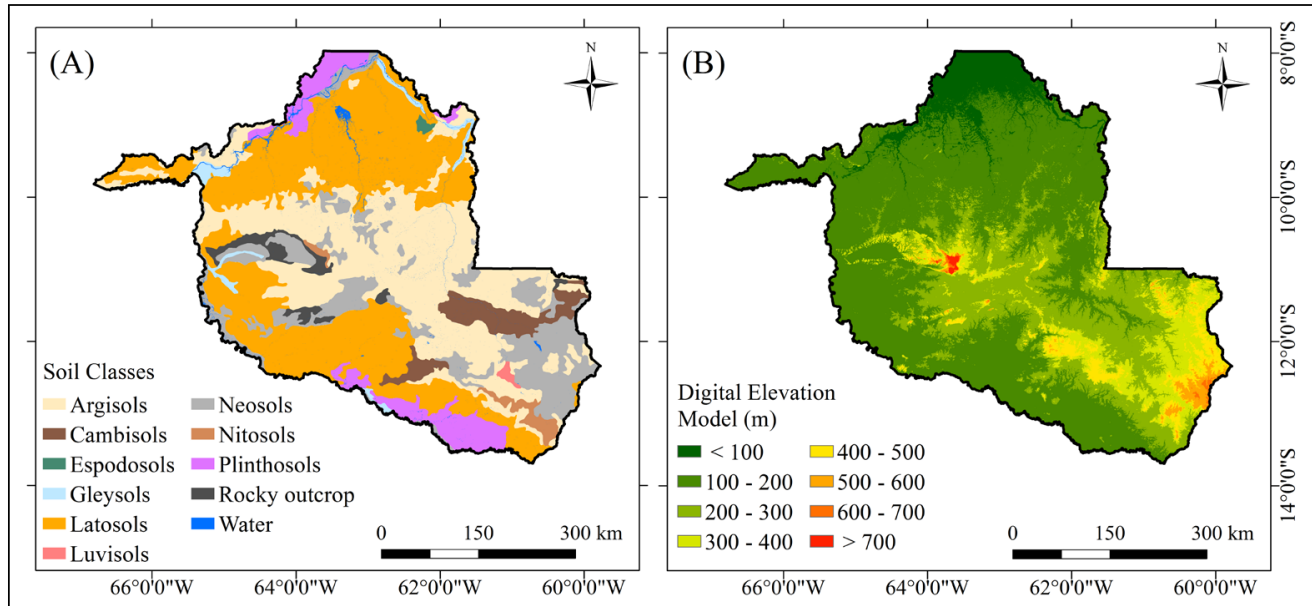

Figure 2 - Digital soil map (A) and digital elevation model (B) of the State of Rondônia, Brazil. The digital soil map was adapted according to IBGE-Embrapa (2001). Total area of each soil class: Argisols $=72,994$ $\mathrm{km}^{2}$; Cambisols $=9,511 \mathrm{~km}^{2} ;$ Espodosols $=476 \mathrm{~km}^{2} ;$ Gleysols $=3,804 \mathrm{~km}^{2} ;$ Latosols $=91,540 \mathrm{~km}^{2}$; Luvisols $=476 \mathrm{~km}^{2} ;$ Neosols $=34,238 \mathrm{~km}^{2} ;$ Nitosols $=3,091 \mathrm{~km}^{2}$ and Plinthosols $=14,741 \mathrm{~km}^{2}$.

regulated by the "Empresa Brasileira de Pesquisa Agropecuária - Embrapa.”

\section{Revised Universal Soil Loss Equation - RUSLE}

The RUSLE model is represented according to Equation 1 .

$\mathrm{A}=\mathrm{R} \cdot \mathrm{K} \cdot \mathrm{LS} \cdot \mathrm{C} \cdot \mathrm{P}$

Where: $\mathrm{A}$ is the average annual soil loss, in $\mathrm{Mg} \mathrm{ha}^{-1}$ year $^{-1}$; $\mathrm{R}$ is the rainfall erosivity factor, in $\mathrm{MJ}$ $\mathrm{mm} \mathrm{ha}^{-1} \mathrm{~h}^{-1}$ year ${ }^{-1}$; $\mathrm{K}$ is the soil erodibility factor, in $\mathrm{Mg} \mathrm{h}$ $\mathrm{MJ}^{-1} \mathrm{~mm}^{-1}$; LS is the topographic factor, dimensionless; $\mathrm{C}$ is the cover and management factor, dimensionless; and $\mathrm{P}$ is the support practices, dimensionless.

The $\mathrm{R}$ factor reflects the effect of the intensity of rainfall on soil erosion, that is, its rainfall erosivity. Due to the lack of detailed data on the duration and intensity of rainfall in Rondônia, the $\mathrm{R}$ factor was determined according to MELLO et al. (2013) (Equation 2). The calculation was performed from each DEM cell using the Raster Calculator tool from the ArcMap 10.3 software (ESRI, 2015).

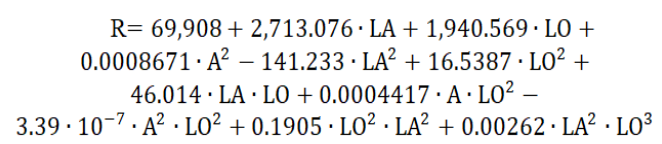

Where: $\mathrm{R}$ is the rainfall erosivity factor, in $\mathrm{MJ} \mathrm{mm} \mathrm{ha}{ }^{-1} \mathrm{~h}^{-1}$ year $^{-1} ; \mathrm{A}$ is the altitude, in meters; LA is latitude, and LO is the longitude, both in negative decimal degree.
The $\mathrm{K}$ factor shows each soil class susceptibility to the erosion process, and the higher its value, the greater is the risk of erosion occurrence. The $\mathrm{K}$ factor is determined according to the soil properties, which are obtained from the sampling points or soil loss plots. However, the large size of the state of Rondônia makes impossible to detail the soil properties for calculating the $\mathrm{K}$ factor by indirect methods. Thus, the parameter it was adopted from values reported in the literature, considering the entire Brazilian territory (Table 1), since no studies indicate the K factor value specifically for the Rondônia soils.

The LS factor represents the influence of the relief on soil losses. This parameter was calculated according to the methodology of Moore and Burch (1986), which is based on the DEM (Equation 3).

$\mathrm{LS}=\left(\frac{\mathrm{FA} \cdot 30}{22.13}\right)^{0.4} \cdot\left(\frac{\sin (\mathrm{S})}{0.0896}\right)^{1.3}$

Where: LS is the topographic factor, dimensionless; FA is the flow accumulation expressed as the number of cells in the DEM grid; $\mathrm{S}$ is the watershed declivity, in degree; and 30 is the spatial resolution of the DEM, in meters.

The S parameter was calculated using the ArcMap 10.3 slope tool (ESRI, 2015). In the region, the average slope is $4.5 \%$, indicating a predominance of smooth wavy relief (3\%-8\%).

The $\mathrm{C}$ factor ranges from zero to one representing the effects of vegetation cover on water erosion rates. In exposed soil areas, $\mathrm{C}$ factor is one, and the higher the levels of vegetation cover on the 
Table 1 - Soil erodibility factor $(\mathrm{K})$.

\begin{tabular}{lccr}
\hline Soil Classes & $\mathrm{K}^{* *}$ & Soil classes & $\mathrm{K}^{* *}$ \\
& $\mathrm{Mg} \mathrm{h} \mathrm{MJ}^{-1} \mathrm{~mm}^{-1}$ & $\mathrm{Mg} \mathrm{h} \mathrm{MJ}^{-1} \mathrm{~mm}^{-1}$ & 0.0312 \\
\hline Argisols & 0.0425 & Luvisols & 0.0510 \\
Cambisols & 0.0508 & Neosols & 0.0237 \\
\hline Espodosols & 0.0590 & Nitosols & 0.0335 \\
Gleysols & 0.0010 & Plinthosols & \\
\hline Latosols & 0.0162 & & \\
\hline
\end{tabular}

*Brazilian Soil Classification System (SANTOS et al., 2018). ${ }^{* *}$ Values adapted from MANNIGEL et al. (2002); SILVA \& ALVARES (2005); GOMES et al. (2017).

soil, the lower the value of $\mathrm{C}$. This parameter was determined based on the Normalized Difference Vegetation Index (NDVI) according to the methodology proposed by DURIGON et al. (2014) (Equation 4).

$$
\mathrm{C}=\frac{-\mathrm{NDVI}+1}{2 \mathrm{NDV}}
$$
indicator of vegetation vigor, with higher values attributed to areas of higher plant density. This index is calculated according to TUCKER (1979) (Equation 5):

NDVI $=\frac{\text { NIR-RED }}{\text { NIR }+ \text { RED }}$

Where: NIR and RED are the spectral bands of the near-infrared $(851-879 \mathrm{~nm})$, and red (636- $673 \mathrm{~nm})$, respectively.

The NDVI was calculated using images from the Landsat- 8 Operational Land Imager (OLI) satellite obtained in the image catalog of the "Instituto Nacional de Pesquisas Espaciais" (INPE). Due to the large extension of the study area, 16 images, dated from July to October 2019, with orbits and points, including the entire state, were selected. Image processing (mosaic composition and image treatments), as well as the NDVI and the $\mathrm{C}$ factor calculations were performed in the ArcMap 10.3 (ESRI, 2015).

The $\mathrm{P}$ factor, conversely varies according to the presence or absence of conservationist management practices of the soil. Once again, the large dimension of the state makes it difficult to determine this parameter in situ. Thus, for each landuse class, values available in the specialized literature were used.

In the other non-vegetated areas, the assigned $\mathrm{P}$ factor value was one, while in agriculture and pasture areas, 0.5, and for the Amazon Forest and other natural vegetation formations, 0.01 (BERTONI
\& LOMBARDI NETO, 2014). All parameters were converted into the raster data format and multiplied among themselves to execute the RUSLE equation, using the Raster Calculator tool of the ArcMap 10.3 (ESRI, 2015).

The estimated soil losses were compared with the soil loss tolerance $(\mathrm{T})$ limits. $\mathrm{T}$ is a parameter reflecting the maximum rate of water erosion that will still allow a level of sustainable crop productivity (WISCHMEIER; SMITH, 1978). The limits adopted were obtained based on the values presented in the literature for Brazilian soils and are represented in table 2.

The RUSLE estimates the total water erosion, including both the eroded soil that stays retained in the relief depressions, as well as those that reach the water bodies in the defluvium area. The estimate of this fraction of soil that reaches the water bodies is possible from the sediment delivery rate coefficient (SDR). Therefore, the SDR was calculated using Equation 6 (VANONI, 1975).

$S D R=0.472 \cdot A^{-0.125}$

Where: SDR is the delivery rate of sediments, in \%; and $\mathrm{A}$ is the watershed area, in $\mathrm{km}^{2}$.

\section{Validation}

TheRUSLEresults were validated according to the methodology of BESKOW et al. (2009). For this purpose, data from a hydrosedimentological station (Figure 1) regulated by the "Agência Nacional de Águas" (ANA), located in a drainage confluence area of $122,000 \mathrm{~km}^{2}$, were used.

The monitoring conducted by ANA did not show enough frequency to monitor the entire hydrological year (only four or five collections per year due to high costs). Thus, to increase the number of samples and the accuracy of the validation, a regression test was made between the data of total 
Table 2 - Soil Loss Tolerance (T).

\begin{tabular}{lccc}
\hline Soil Classes & & $\mathrm{T}^{* *}$ & Soil classes \\
& $\mathrm{Mg} \mathrm{ha}^{-1}$ year $^{-1}$ & & $\mathrm{Mg} \mathrm{ha}^{-1} \mathrm{year}^{-1}$ \\
Luvisols & 3.25 & Nitosols & 11.10 \\
Espodosols & 7.79 & Latosols & 12.73 \\
Argisols & 8.61 & Cambisols & 13.65 \\
Neosols & 10.48 & Gleysols & 14.14 \\
Plinthosols & 11.00 & & \\
\hline
\end{tabular}

Notes: Soil loss Tolerance (T) * Brazilian Soil Classification System (SANTOS et al., 2018). ${ }^{* *}$ Values adapted from MANNIGEL et al. (2002), MARTINS et al. (2010) and NUNES et al. (2012).

sediments transported with the discharge of water and flow, monitored between the years 1984 and 2019 (Figure 3). Then, the annual sediment transported in 2019 was calculated considering the linear regression $(y=0.018 x+11.619)$ and the daily runoff data set for the area.

\section{RESULTS AND DISCUSSION}

The rainfall erosivity ( $\mathrm{R}$ factor) of the state of Rondônia ranged between 8,962 to $12,409 \mathrm{MJ} \mathrm{mm}$ $\mathrm{ha}^{-1} \mathrm{~h}^{-1}$ year ${ }^{-1}$ (Figure 4A), which is in agreement with was observed by MELLO et al. (2013). These authors classified the erosivity on the State as compelling, due to the high rainfall rate in the Amazon region. The LS factor had an average of 1.3 (Figure 4B), indicating that $97 \%$ of the state has relief with low vulnerability to erosion. Conversely, in $3 \%$ of the region area, the LS factor was greater than 10, and these areas are classified as highly vulnerable to water erosion (BESKOW et al., 2009).

A large part of these steep relief areas is part of the Pacaás Novos National Park (PNPN), a Conservation Unit (UC) of full protection, created by Decree $n^{\circ} 84019$ of 1979 . The Park has an area of 708,669.90 ha, and its creation protected the ecosystems by controlling the activities developed in these areas, such as scientific research, educational activities, and ecological tourism (BRASIL, 2000).

Thus, as these are areas destined to the integral conservation of natural resources, they have natural protection against the acceleration of the erosive process caused by human activities. However, in the state of Rondônia, there are still steep areas that are not part of any UC, although, according to the Forest Code, Law 12,651 of 2012 (BRASIL, 2012), any steep slope higher than $45^{\circ}$ constitutes a Permanent Preservation Area.

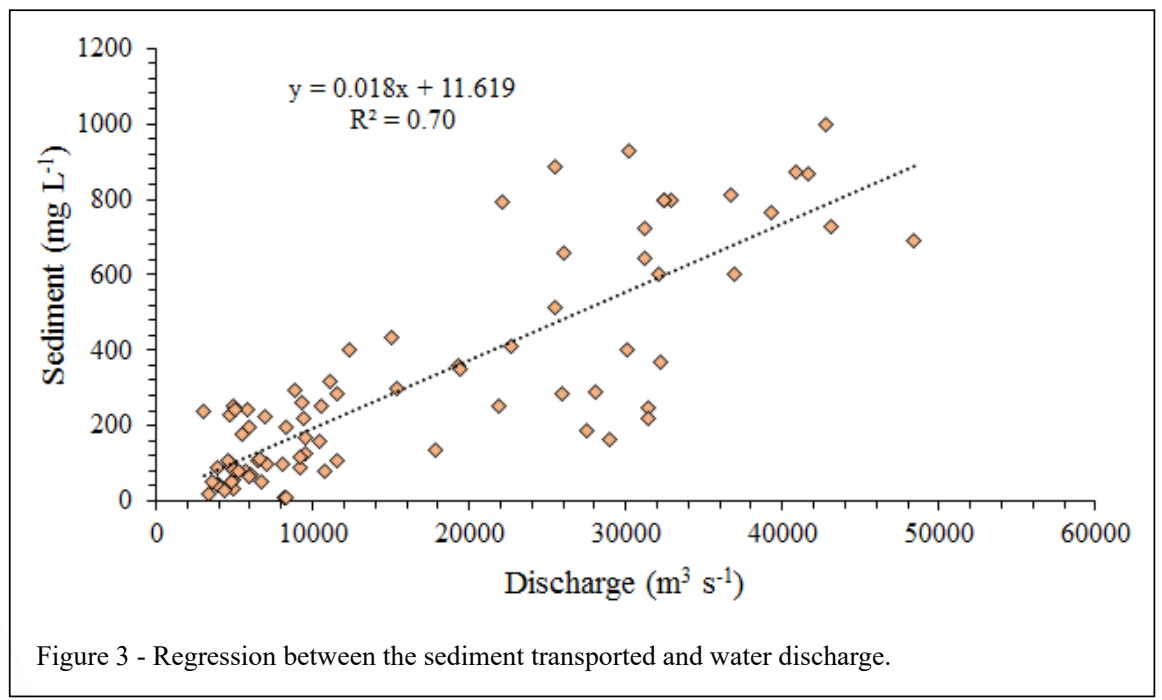

Ciência Rural, v.51, n.5, 2021. 


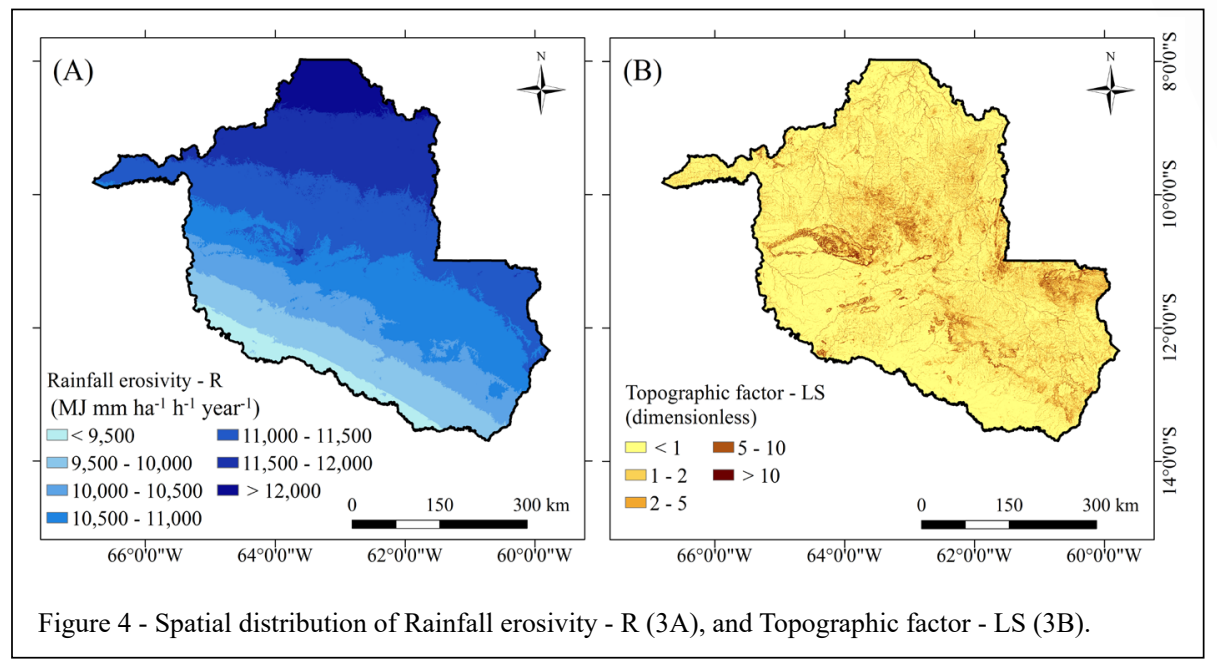

Therefore, in these locations, practices aiming soil conservation must be respected and encouraged, since they are not areas controlled as the UC, but are vulnerable to the energy gain of the runoff due to the topography, intensifying the erosion process (STEINMETZ et al., 2018).

The NDVI of the state of Rondônia shows higher values in the forest areas, showing high plant density (Figure 5A). Low NDVI values were observed in the areas of exposed soil and pastures, indicating the degradation of these sites. According to DIAS-FILHO (2014), most pastures of the region are degraded, which was also confirmed by the vegetation index.
As for the $\mathrm{C}$ factor, it is normalized between 0 and 1 and inversely proportional to NDVI, so the lowest values of the parameter were observed in the Amazon Forest areas (Figure 5B), indicating good soil protection by the vegetation cover.

It is worth mentioning that most studies that apply RUSLE to Brazilian soils use the methodology for determining the $\mathrm{C}$ factor based on values reported in the literature (BESKOW et al., 2009; BATISTA et al., 2017). However, the adoption of a static value, especially at large scales, cannot represent the heterogeneity of vegetation density. The calculation of C factor using NDVI, allows estimating

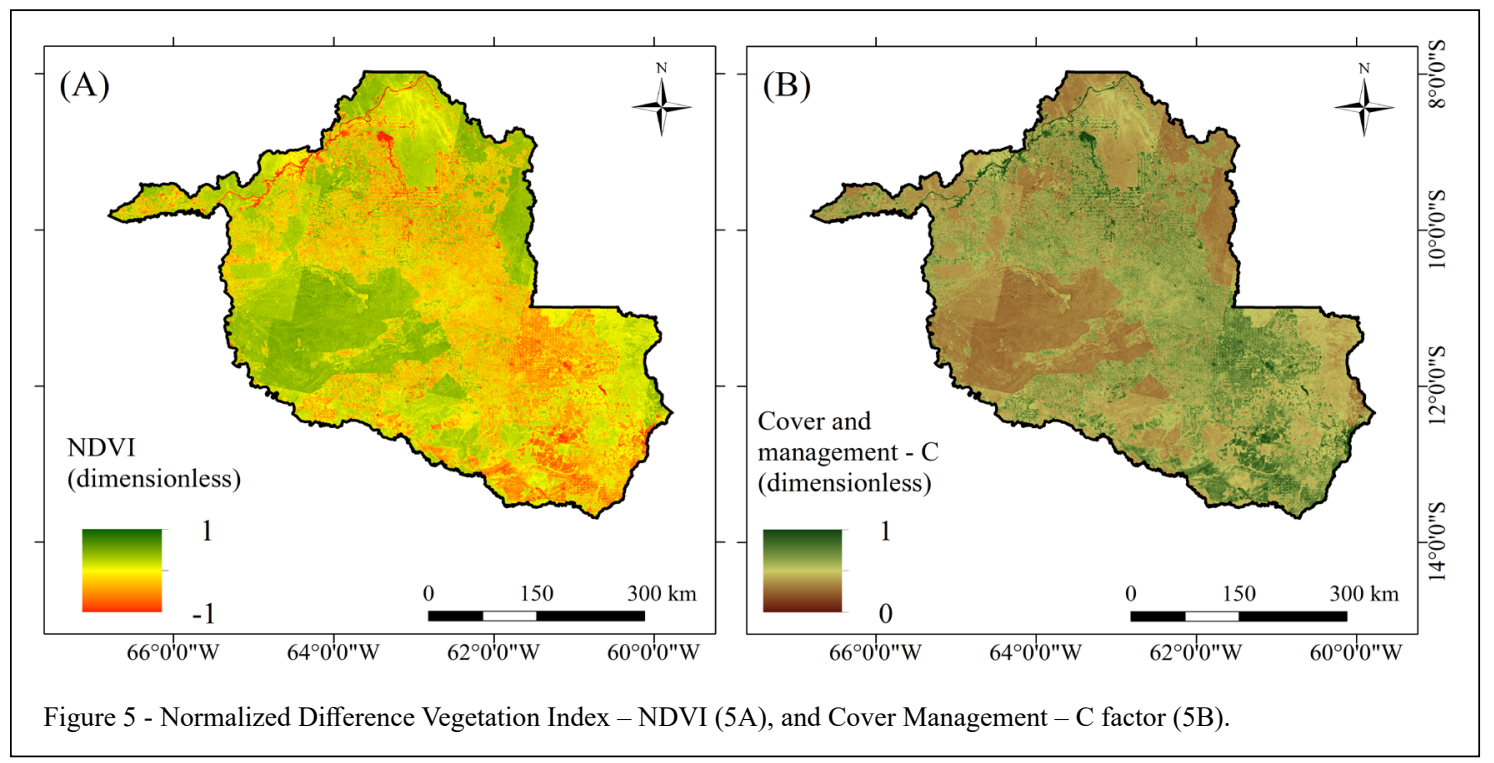

Ciência Rural, v.51, n.5, 2021. 
the vegetation cover from each pixel of a satellite image, and thus, it is a more accurate representation of the vegetation cover compared to values present in the literature, which were often calculated from researches developed in different regions (LENSE et al., 2020). Also, the methodology of DURIGON et al. (2014), was developed for Brazilian tropical conditions, showing accurate results to determine the spatial and temporal dynamics of $\mathrm{C}$ factor in large areas (ALMAGRO et al., 2019; LENSE et al., 2020). Thus, the $\mathrm{C}$ factor was effective in representing variations in vegetation cover in Rondônia.

The total soil loss estimated by RUSLE was about 605 million tons per year, corresponding to an average loss of $22.50 \mathrm{Mg} \mathrm{ha}^{-1}$ year $^{-1}$. The spatialization of soil losses, obtained by the RUSLE, is represented in Figure 6. Comparing the results of soil loss with T, it was observed that in $19 \%$ of the State of Rondônia the erosive rate was higher than the tolerable limits, thus generating intense soil degradation. These areas are located mainly in places with high LS values and low rates of vegetation cover.

In the state of Rondônia, high soil loss was observed in pasture areas $\left(62.85 \mathrm{Mg} \mathrm{ha}^{-1}\right.$ year ${ }^{1}$ ), which occurred mainly due to the low rate of vegetation cover in this class of use, which was verified through NDVI (Figure 5A), and incorporated into RUSLE through $\mathrm{C}$ factor (Figure 5B). The soil losses were higher in non-vegetated areas (77.30 $\mathrm{Mg} \mathrm{ha}^{-1}$ year ${ }^{-1}$ ) and agriculture $\left(32.70 \mathrm{Mg} \mathrm{ha}^{-1}\right.$ year $\left.{ }^{1}\right)$, and minors in forests $\left(2.24 \mathrm{Mg} \mathrm{ha}^{-1}\right.$ year $\left.^{-1}\right)$ and other natural formations $\left(1.50 \mathrm{Mg} \mathrm{ha}^{-1}\right.$ year $\left.^{-1}\right)$. As for soil classes, water erosion was greater for those with higher $\mathrm{K}$ factor values (Table 1 ), especially when combined with land-use types with lower vegetation density (Table 3).

Together Argisols and Neosols make up most of the territory of the State of Rondônia (45.1\%). These soils have low resistance to water erosion and when they were occupied by classes of use with little or no vegetation cover, they reached soil losses above their T limits (Table 2), reaching critical levels of water erosion (Table 3). Even Latosols, which are soils with higher resistance to the erosion process and with a low erodibility, presented high losses ( $>12.73$ $\mathrm{Mg} \mathrm{ha}^{-1}$ year $\left.^{-1}\right)$ in areas with pasture and agriculture (Table 3). In the state of Rondônia there is compelling erosivity, so all the soils in the area are subject to high erosion rates; and therefore, management practices, changes in land use and variations in vegetation cover play an important role in reducing erosion rates, especially in soils most vulnerable to water erosion.

Results point to the need for planning, implementation, and dissemination of more effective

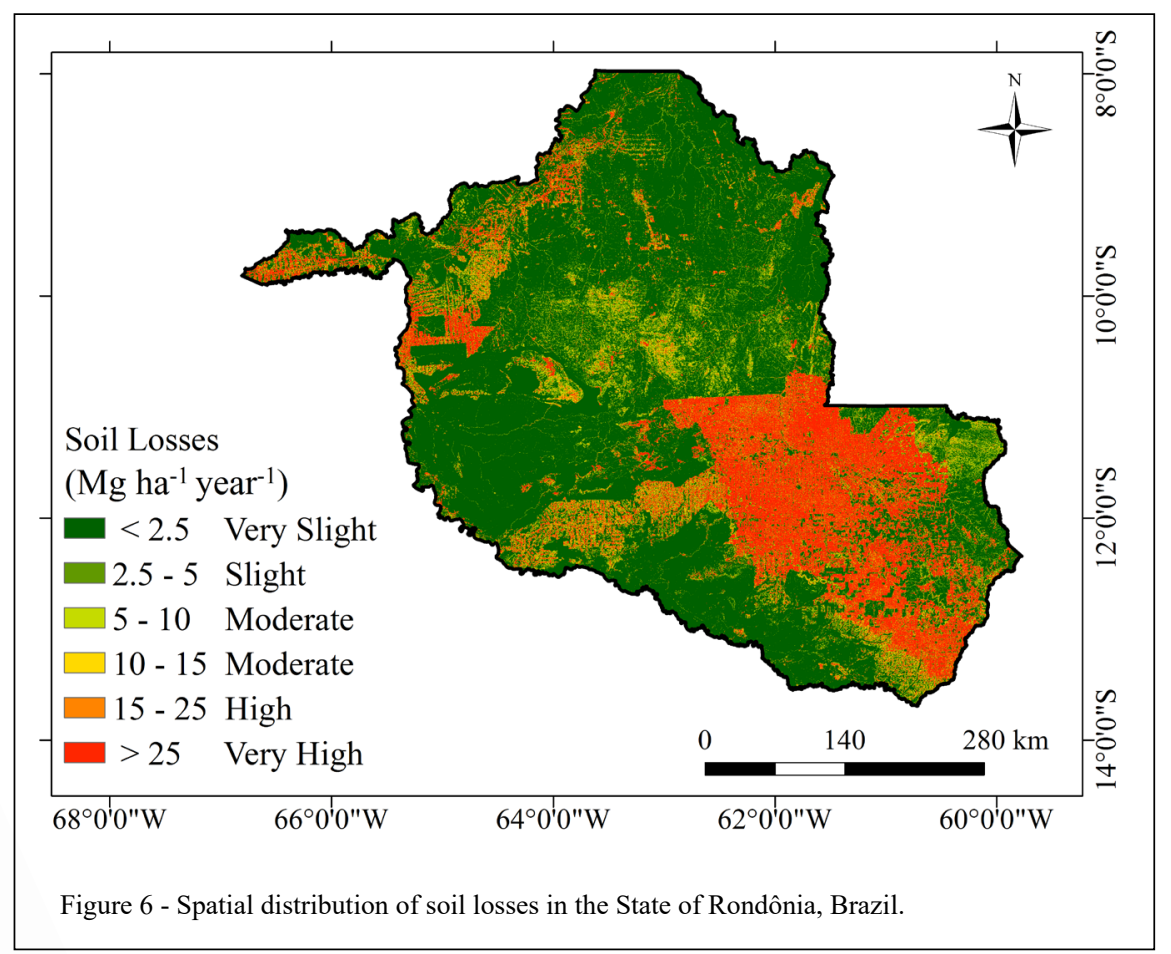

Ciência Rural, v.51, n.5, 2021. 
Table 3 - Estimation of soil loss by soil class and respective land-use in the state of Rondônia, Brazil.

\begin{tabular}{|c|c|c|c|c|c|}
\hline Soil Classes & Amazon forest & Pastures & Agriculture & Other natural formations & $\begin{array}{c}\text { Other non-vegetated } \\
\text { areas }\end{array}$ \\
\hline & \multicolumn{5}{|c|}{ 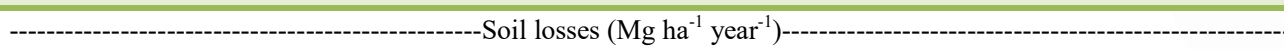 } \\
\hline Argisols & 2.70 & 79.52 & 48.75 & 8.12 & 181.85 \\
\hline Cambisols & 4.30 & 79.71 & 50.49 & 2.90 & 125.40 \\
\hline Espodosols & 1.60 & 40.25 & 39.33 & 3.40 & - \\
\hline Gleysols & 0.04 & 1.90 & 8.20 & 0.09 & - \\
\hline Latosols & 0.65 & 24.50 & 16.75 & 0.81 & 69.38 \\
\hline Luvisols & 4.96 & 68.39 & 37.86 & 22.55 & - \\
\hline Neosols & 4.10 & 109.60 & 62.14 & 3.92 & 70.68 \\
\hline Nitosols & 3.67 & 70.68 & 27.70 & 7.15 & - \\
\hline Plinthosols & 0.80 & 39.62 & 25.22 & 0.40 & 42.62 \\
\hline
\end{tabular}

soil management techniques and conservation practices for agricultural and pasture areas, as well as the reduction of exposed soil areas, to reduce areas with an erosion rate higher than the $\mathrm{T}$ limits. Also, participation and encouragement by State and Municipal Governments, in partnership with the Federal Government, is essential to popularize conservationist practices and to elaborate a broad erosion mitigation plan. According to MONTANARELLA (2015) and ALEWELL et al. (2019), high rates of soil losses occur, not because of a lack of knowledge on how to protect soils, but because of a lack of public policies for their conservation.

It is worth mentioning that, to achieve the reduction of soil losses, it is also necessary to reduce deforestation since the State of Rondônia has high rates of this process (INPE, 2020), and the conversion of native vegetation to agricultural land or pasture can intensify water erosion.

Also, in the long term, adequate land-use should be sought according to its agricultural potential and suitability, due to the high presence of areas with soils vulnerable to water erosion occupied by degraded pastures (47.80; 43.40 and 26.60\% of Argisols, Cambisols, and Neosols, respectively). According to MEDEIROS et al. (2016), public policies must be developed and implemented to the potential and capacity of land-use to be considered primary factors to determine the sustainable agricultural use of natural resources.

The SDR obtained using Equation 6 was 0.109 , indicating that approximately $11 \%$ of all eroded soil in the region reaches watercourses causing silting and depreciation of water quality. Thus, the estimated sediment transport was $2.45 \mathrm{Mg} \mathrm{ha}^{-1}$ year $^{-1}$. Based on results of total solids and an average flow, of 22,37 $\mathrm{m}^{3} \mathrm{~s}^{-1}$, we calculated the observed sediment as 3.01 $\mathrm{Mg} \mathrm{ha}^{-1}$ year $^{-1}$.
Comparing the values, the RUSLE underestimated the generation of sediments in $0.56 \mathrm{Mg} \mathrm{ha}^{-1}$ year $^{-1}$, which corresponds to an error of $18.60 \%$. According to PANDEY et al. (2007), errors under $20 \%$ can be considered acceptable. Therefore, the results obtained are reliable and can assist in the planning of water erosion mitigation measures in Rondônia.

Regardless of the errors, large-scale modeling should be interpreted as a tool to assess the magnitude of the erosion process, as well as trends over time, system responses to determining factors, soil use and management practices. Moreover, soil erosion modeling is crucially necessary for the planning of public policies mitigated this process (ALEWELL et al., 2019).

\section{CONCLUSION}

The state of Rondônia presents high erosivity, soil classes with different erodibilities, and predominantly, reliefs with low vulnerability to erosion. Therefore, vegetation cover and management of support practices were the main factors responsible for the soil loss variations.

The RUSLE estimated water erosion with acceptable precision, indicating that, in $19 \%$ of the State of Rondônia, soil losses were greater than the tolerable limits $(\mathrm{T})$, and these areas should be prioritized for adopting measures to mitigate the process.

Results of this study can contribute to the elaboration of different soil management scenarios, as well as to provide alternatives to agricultural and environmental policymakers, encouraging soil conservation in the state of Rondônia. 


\section{ACKNOWLEDGEMENTS}

The authors thank the "Fundação de Amparo à Pesquisa do Estado de Minas Gerais" (FAPEMIG) for the scholarship offered to the first author. This study was financed in part by the "Coordenação de Aperfeiçoamento de Pessoal de Nível Superior - Brasil” (CAPES) - Finance Code 001.

\section{DECLARATION OF CONFLICTS OF INTERESTS}

The authors declare no conflict of interest. The founding sponsors had no role in the design of the study; in the collection, analysis, or interpretation of data; in the writing of the manuscript, and in the decision to publish the results.

\section{AUTHORS' CONTRIBUTIONS}

All authors contributed equally for the conception and writing of the manuscript. All authors critically revised the manuscript and approved of the final version.

\section{REFERENCES}

ALEWELL, C. et al. Using the USLE: Chances, challenges and limitations of soil erosion modeling. International Soil and Water Conservation Research, v.7, n.3, p.203-225, 2019. Available from: <https://doi.org/10.1016/j.iswcr.2019.05.004>. Accessed: Jan. 20, 2020. doi: 10.1016/j.iswcr.2019.05.004

ALMAGRO, A. et al. Improving cover and management factor (C-factor) estimation using remote sensing approaches for tropical regions.International Soil and Water Conservation Research, v.7, n.4, p.325-334, 2019. Available from: <https://doi. org/10.1016/j.iswcr.2019.08.005>. Accessed: Aug. 24, 2020. doi: 10.1016/j.iswer.2019.08.005.

ALVARES, C. A. et al. Köppen's climate classification map for Brazil. MeteorologischeZeitschrift, v.22, n.6, p.711-728, 2013. Available from: <https://doi.org/10.1127/0941 2948/2013/0507>. Accessed: Apr. 20, 2020. doi: 10.1127/0941-2948/2013/0507.

BARROS, E. N. S.; et al. Modelagem da erosão hídrica was bacias hidrográficas dos rios Lontra e Manoel Alves Pequeno, Tocantins. Revista Brasileira de Ciências Agrárias, v.13, n.1, e5509, 2018. Available from: <http://agraria.pro.br/ojs-2.4.6/index.php?jour nal $=$ agraria\&page $=$ article $\&$ op $=$ view $\&$ path $\% 5 \mathrm{~B} \% 5 \mathrm{D}=$ agraria v13i1a5509\&path $\% 5 B \% 5 \mathrm{D}=5033>$. Accessed: Apr. 25, 2020. doi: 10.5039/agraria.v13i1a5509.

BATISTA, P. V. G.et al. Modeling spatially distributed soil losses and sediment yield in the upper Grande River Basin - Brazil. Catena, v.157, n.1, p.139-150, 2017. Available from: $<$ https://doi. org/10.1016/j.catena.2017.05.025>. Accessed: Apr. 27, 2020. doi: 10.1016/j.catena.2017.05.025.

BERTONI, J.; LOMBARDI NETO, F. Conservação do solo. 4 ed. São Paulo: Ícone, 2014. 355p.

BESKOW, S. et al. C. Soil erosion prediction in the Grande River Basin, Brazil using distributed modeling. Catena, v.79, n.1, p.49-59, 2009. Available from: $<$ https://doi.org/10.1016/j.catena.2009.05.010>. Accessed: Apr. 27, 2020. doi: 10.1016/j.catena.2009.05.010.
BRASIL. Lei Federal. Sistema Nacional de Unidades de Conservação da Natureza - Lei n⿳0 9.985, DF: Congresso Federal, 2000. Available from: <http://www.planalto.gov.br/ccivil_03/leis/ 19985.htm>. Accessed: May, 05, 2020.

BRASIL. Lei Federal. Código Florestal Brasileiro - Lei $\mathbf{n}^{\mathbf{0}}$ 12.651, DF: Congresso Federal, 2012. Available from: <http:// www.planalto.gov.br/ccivil_03/_ato2011 2014/2012/lei/112651. htm>. Accessed: May, 05, 2020.

DIAS-FILHO, M. B. Diagnóstico das passages no Brasil. Embrapa Amazônia Oriental-Documentos, 2014. Available from: $<$ https:// www.infoteca.cnptia.embrapa.br/bitstream/doc/986147/1/ DOC402.pdf>. Accessed: Apr. 27, 2020.

DURIGON, V. L. et al. NDVI time series for monitoring RUSLE cover management factor in a tropical watershed. International Journal of Remote Sensing, v.35, n.2, p.441-453, 2014. Available from: <https://doi.org/10.1080/01431161.2013.871081 >. Accessed: Apr. 15, 2020. doi: 10.1080/01431161.2013.871081.

ESRI - Environmental Systems Research Institute. ARCGIS Professional GIS for the desktop version 10.3. Redlands, Califórnia, Software, 2015. Available in: <https://desktop.arcgis. com/en/arcmap/10.3/get-started/quick-start-guides/arcgisdesktop-quick-start-guide.htm>. Accessed: Jan. 05, 2020.

GANASRI, B. P.; RAMESH, H. Assessment of soil erosion by RUSLE model using remote sensing and GIS - A case study of Nethravathi Basin. Geoscience Frontiers, v.7, n.6, p.953 961, 2016. Available from: $<$ https://doi.org/10.1016/j.gsf.2015.10.007>. Accessed: Apr. 15, 2020. doi: 10.1016/j.gsf.2015.10.007.

GOMES, L. et al. Using Geotechnology to Estimate Annual Soil Loss Rate in the Brazilian Cerrado. Journal of Geographic Information System, v.9, n.1, p.420-439, 2017. Available from: $\quad<$ https://www.scirp.org/journal/paperinformation. aspx?paperid=78043>. Accessed: Jan. 25, 2020. doi: 10.4236/ jgis.2017.94026.

IBGE - Instituto Brasileiro de Geografia e Estatística. EMBRAPA - Empresa Brasileira de Pesquisa Agropecuária. Mapa de Solos do Brasil. Rio de Janeiro: IBGE, 2001-Escala 1:5.000.000.

INPE - Instituto Nacional de Pesquisas Espaciais. Project PRODES Monitoramento do Desmatamento da Floresta Amazônica Brasileira por Satélite. Ministério da Ciência, Tecnologia, Inovações e Comunicações, 2020. Available from: $<$ https://www.obt.inpe.br/OBT/assuntos/programas/amazonia/ prodes $>$. Accessed: Jan. 25, 2020.

LENSE, G. H. E. et al. Estimation of sediments produced in a subbasin using the Normalized Difference Vegetation Index. Ciência e Agrotecnologia, v.44, e031419, 2020. Available from: $<$ https://doi.org/10.1590/1413-7054202044031419>. Accessed: Aug. 24, 2020. doi: 10.1590/1413-7054202044031419.

MANNIGEL, A. R. et al. Fator erodibilidade e tolerância de perda dos solos do Estado de São Paulo. Acta Scientiarum, v.24, n.5, p.1335-1340, 2002. Available from: <https://doi.org/10.4025/ actasciagron.v24i0.2374>. Accessed: Jan. 25, 2020. doi: 10.4025/ actasciagron.v24i0.2374.

MARTINS, S. G. et al. Fator cobertura e manejo do solo e perdas de solo e água em cultivo de eucalipto e em Mata Atlântica nos Tabuleiros Costeiros do estado do Espírito Santo. Scientia. 
Forestalis, v.38, n.87, p.517-526, 2010. Available from: <http:// dcs.ufla.br/images/imagens_dcs//pdf/Prof\%20Marx/Aula\%204/ Art\%20estudo/Martins\%20et\%20al\%202010.pdf $>$. Accessed: Sep. 15, 2020.

MAPBIOMAS PROJECT. Coleção 4 Série Anual de Mapas de Cobertura e Uso de Solo do Brasil, 2018. Available from: $<$ https://plataforma.mapbiomas.org/map\#coverage $>$. Accessed: Jan. 15, 2020.

MEDEIROS, G. O. R. et al. Estimates of annual soil loss rates in the State of São Paulo, Brazil. Revista Brasileira de Ciência do Solo, v.40, e0150497, 2016. Available from: <http://dx.doi.org/1 0.1590/18069657rbcs20150497>. Accessed: Jan 25, 2020. Epub 19-dez-2016. doi: 10.1590/18069657rbcs20150497. (Electronic publication).

MELLO, C. R.et al. Multivariate models for annual rainfall erosivity in Brazil. Geoderma, v.203, n.1, p.88-102, 2013. Available from: $<$ https://doi.org/10.1016/j.geoderma.2013.03.009>. Accessed: Jan 20, 2020. doi: 10.1016/j.geoderma.2013.03.009

MIRANDA, E. E. de. Brasil em Relevo. Campinas: Embrapa Monitoramento por Satélite, 2005. Available from: <https:// www.cnpm.embrapa.br/projetos/relevobr/download/ro/ro.htm>. Accessed: Aug. 24, 2020.

MONTANARELLA, L. Govern our soils. Nature, v.528, p.32-33, 2015. Available from: <https://www.nature.com/news/polopoly fs/1.18854!/menu/main/topColumns/topLeftColumn/pdf/528032a. pdf $>$. Accessed: Apr. 20, 2020.

MOORE, I. D.; BURCH, G. J. Physical basis of the length slope factor in the Universal Soil Loss Equation. Soil Science Society of America, v.50, n.5, p.1294-1298, 1986. Available from: <https:// doi.org/10.2136/sssaj1986.03615995005000050042x>. Accessed: Jan. 20, 2020. doi: 10.2136/essay1986.03615995005000050042x.

NUNES, J. G. et al. Tolerância de perda de solo por erosão na região sul do Amazonas. Ambiência, v.8, n.3, p.859-868, 2012. Available from: <https://revistas.unicentro.br/index.php/ ambiencia/article/view/1536>. Accessed: Aug. 24, 2020. doi: 10.5777/ambiencia.2012.05.05

PANAGOS, P.; KATSOYIANNIS, A. Soil erosion modelling: The new challenges as the result of policy developments in Europe. Environmental Research, v.172, n.1, p.470-474, 2019. Available from: $<$ https://doi.org/10.1016/j.envres.2019.02.043>. Accessed: Apr. 28, 2020. doi: 10.1016/j.envres.2019.02.043.
PANDEY, A. et al. Identification of critical erosion prone areas in the small agricultural watershed using USLE, GIS and remote sensing. Water Resources Management, v.21, n.1, p.729-746, 2007. Available from: <https://doi.org/10.1007/s11269-006-9061-z>. Accessed: Apr. 28, 2020. doi: 10.1007/s11269-006-9061-z.

PIONTEKOWSKI, V. J. et al. Avaliação do Desmatamento no Estado de Rondônia entre 2001 e 2011. Floresta e Ambiente, v. 21, n. 3, p. 297-306, 2014.Available from: <https://doi. org/10.1590/2179-8087.068213>. Accessed: Apr. 15, 2020. doi: $10.1590 / 2179-8087.068213$.

RENARD, K. G. et al. Predicting soil erosion by water: a guide to conservation planning with the Revised Universal Soil Loss Equation (RUSLE). 1. ed. Washington: United States Department of Agriculture, 1997. 407p.

SANTOS, H. G.et al. Sistema Brasileiro de Classificação de Solos. 5. ed. rev. amp. Brasília: Embrapa, 2018. 355p.

SCHLINDEWEIN, J. A. et al. Solos de Rondônia: Usos e Perspectivas. Revista Brasileira de Ciência da Amazônia, v.1, n.1, p.213-231, 2012. Available from: <http://www.periodicos.unir.br/index.php/ rolimdemoura/article/view/612>. Accessed: Apr. 15, 2020.

SILVA, A. M.; ALVARES, C. A. Levantamento de informações e estruturação de um banco de dados sobre a erodibilidade de classes de solos no Estado de São Paulo. Geociências, v.24, n.1, p.33-42, 2005. Available from: <http://www.ppegeo.igc.usp.br/index.php/ GEOSP/article/view/9738>. Accessed: Jan. 15, 2020.

STEINMETZ, A. A. et al. Assessment of soil loss vulnerability in data-scarce watersheds in southern Brazil. Ciência e Agrotecnologia, v.42, n.6, p.575-587, 2018. Available from: $<$ http://dx.doi.org/10.1590/1413-70542018426022818> Accessed: Jan. 15, 2020.doi: 10.1590/1413-70542018426022818.

TUCKER, C. J. Red and photographic infrared linear combination for monitoring vegetation. Remote Sensing of Environment, v.8, n.2, p.127-150, 1979. Available from: <https://doi. org/10.1016/0034-4257(79)90013-0>. Accessed: Jan. 15, 2020. doi: $10.1016 / 0034-4257(79) 90013-0$.

VANONI, V. A. Sediment deposition engineering. 1. ed. Washington: American Society of Civil Engineers, 1975. 745p.

WISCHMEIER, W. H; SMITH, D. D. Predicting rainfall erosion losses. A guide to conservation planning. 1st. Washington: United States Department of Agriculture. Supersedes Agriculture Handbook, 1978. 58p. 